\title{
EVALUATION OF INTRATHECAL NEOSTIGMINE IN DIFFERENT DOSES ADDED TO BUPIVACAINE FOR POSTOPERATIVE ANALGESIA
}

\author{
Mubasher Ahmad Bhat ${ }^{1}$, Mohamad Ommid ${ }^{2}$ *Arun Kumar Gupta ${ }^{3}$, Zahoor Ahmad Shah ${ }^{4}$ \\ , Faisal Ismail ${ }^{5}$ Gousia Nisa Resident ${ }^{6}$, Sheeba Nazir ${ }^{7}$, Shigufta Qazi ${ }^{8}$ \\ Dept of Anaesthesiology \& Critical Care. SKIMS, Soura, Srinagar, J\&K, India ${ }^{1,2,4,5,6,7,8 \text {, }}$ \\ Assistant Professor, Dept of Anaesthesiology \& Critical Care, Rural Medical College, Loni. \\ Maharashtra. India ${ }^{3}$,
}

*Corresponding author: guptaarun71@ gmail.com

Key words: Bupivacaine, Neostigmine, Spinal Anaesthesia

\begin{abstract}
Background: Neuraxial administration of neostigmine alongwith local anaesthetics improves the quality of intraoperative analgesia and also provides postoperative pain relief for longer duration. The present study was conducted to study the efficacy and safety of intrathecal neostigmine with bupivacaine in two different doses.
\end{abstract}

\begin{abstract}
Methods: Ninety patients of ASA I and II undergoing lower abdominal and lower limb surgeries under spinal anaesthesia were enrolled and divided into 3 groups of 30 each.

Group A: bupivacaine control group, Group B: bupivacaine plus 50mcg neostigmine and Group C; bupivacaine plus $150 \mathrm{mcg}$ neostigmine. Haemodynamic parameters, sensory and motor characteristics along with side effects were recorded. The post operative pain assessment was done by visual analogue scale score at hourly intervals for the first four hours, then two hourly intervals for the next 6 hours and thereafter at 24 hours. It was scaled from a score of 0 meaning no pain to a score of 100 meaning worst pain perceived. Time of two segment regression of sensory blockade and total duration of motor block was significantly prolonged in group $\mathrm{B}$ and $\mathrm{C}$ as compared to the control group.
\end{abstract}

Results: The mean total duration for analgesia was significantly prolonged in Group B $(340 \pm 8.36)$ and Group C $(700 \pm 8.65)$ when compared to group A $(263.30 \pm 7.57)(\mathrm{p}<0.05)$.

Conclusion: We conclude that intrathecal neostigmine results in effective postoperative analgesia prolonging sensory and motor block without hemodynamic and respiratory depression in the intra and postoperative period.

International Association for the study of Pain defined pain as an "unpleasant sensation and an emotionally charged experience associated with actual or potential tissue damage or described in terms of such damage". Because of concern over intra spinal opioid induced side effects other drugs have also been examined for spinal analgesia, notably $\alpha_{2}$ agonists like clonidine, $\mathrm{N}$ methyl D aspartate (NMDA) antagonists like ketamine and anticholinesterases like neostigmine. Intrathecal neostigmine represents a novel approach to provide analgesia. It inhibits the breakdown of an endogenous spinal neurotransmitter acetylcholine which has been shown to have antinociceptive actions. Acetylcholine released from preganglionic sympathetic ganglia has been shown to have action at other spinal sites like inhibition of motor neuron activity, excitation of sympathetic outflow. $^{2}$ Spinal neostigmine is advantageous over other currently used spinal drugs as it causes no hypotension (excitation of sympathetic outflow), no sedation, no respiratory depression or neurological dysfunction. ${ }^{2,3}$ Bupivacaine was the first local anaesthetic that produced adequate pain relief, without a major effect on motor fibres. ${ }^{4}$ Neostigmine has been shown to counteract haemodynamic effects of clonidine and bupivacaine. ${ }^{5,6}$ Considering the above facts, we designed the present study to evaluate efficacy and safety of intrathecal bupivacaine alone and in combination with neostigmine for postoperative analgesia.

Materials and Methods

After Institutional Ethics Committee clearance and written informed consent from patients, 
ninety patients undergoing lower abdominal and lower limb surgeries under spinal anaesthesia participated in the study. The patients were in the age group of 20 to 40 years of both sexes and belonging to ASA physical status Grade I and II. Following patients were excluded from the study: Unconscious or mentally retarded, drug addicts, weight $>100 \mathrm{~kg}$, bleeding disorders or on anticoagulant therapy, known allergy to the study drugs and local infection at the site of injection. In the preoperative visit on the evening before surgery, the method of postoperative pain scoring was explained and a training given to all patients.

The patients were randomly allocated to three groups:-

Group $\mathrm{A}(\mathrm{n}=30)$ received $2.5 \mathrm{ml}$ intrathecal bupivacaine $0.5 \%$ (Control group)

Group B $(\mathrm{n}=30)$ received 50 $\mu \mathrm{g}$ intrathecal neostigmine $+2.5 \mathrm{ml}$ bupivacaine $0.5 \%$

Group $\mathrm{C}(\mathrm{n}=30)$ received $150 \mu \mathrm{g}$ intrathecal neostigmine $+2.5 \mathrm{ml}$ bupivacaine $0.5 \%$

Neostigmine was measured and taken to an insulin syringe and mixed with bupivacaine. The observer was blinded to the group the patient belonged to.

Preanesthetic checkup of all the patients was done prior to the day of surgery. Patients were kept fasting for 8 hours prior to the surgery and received tablet ranitidine $150 \mathrm{mg}$ at bed time and 2 hours preoperatively as premedication with a sip of water. On arrival in the operation theatre heart rate (ECG), blood pressure (NIBP), respiratory rate, and arterial $\mathrm{O}_{2}$ saturation $(\mathrm{SaO} 2)$ were monitored. An infusion of normal saline was started in all patients and preloaded with $10 \mathrm{ml} / \mathrm{kg}$ of normal saline. Patients were placed in lateral or sitting position according to their convenience. Lumbar puncture was performed with 23 or 25 gauge Quincke's needle in $\mathrm{L}_{2} \mathrm{~L}_{3}$ or $\mathrm{L}_{3} \mathrm{~L}_{4}$ intervertebral space. After obtaining free flow of clear cerebrospinal fluid, bupivacaine alone or in combination with neostigmine was administered depending upon the group. Patients were immediately turned supine after administration of subarachnoid block. All patients received $21 /$ min oxygen throughout the surgical procedure. Level of sensory block was determined using the pin prick method. Motor block was assessed by Bromage scale:

Grade III inability to move leg or feet

Grade II able to move feet only
Grade I just able to flex knees and full flexion of feet possible

Grade 0 full flexion of knee and feet, able to lift leg

Time from start of anaesthesia to Bromage grade II was noted. Time of 2 segment regression of sensory blockade and time of motor blockade to Bromage Grade 0 was checked and recorded every 15 minutes after completion of surgery. Intraoperative haemodynamic stability was ensured. Post operative pain assessment was done by visual analogue scale score at hourly intervals for the first four hours, then two hourly for the next 6 hours and thereafter at 24 hours. It was scaled from a score of 0 meaning no pain to a score of 100 meaning worst pain perceived. Patients with VAS above 40 received rescue analgesia in the form of injection diclofenac sodium $75 \mathrm{mg}$ $\mathrm{i} / \mathrm{m}$. Time to analgesic dose required in the postoperative period and VAS score was assessed. Occurrence of nausea, vomiting, increased salivation, sweating, sedation, hypotension and bradycardia were noted. The patients were given injection Ondansetron 4mg $\mathrm{i} / \mathrm{v}$ for nausea and vomiting. Statistical analysis was done by SPSS 2 software using ANOVA and chi square. A $p$ value of $<0.05$ was considered statistically significant.

\section{Results}

Three groups were comparable with respect to age, weight, baseline $\mathrm{SpO}_{2}$, blood pressure and heart rate.

An adequate surgical block was documented before start of surgery and the time taken to reach this level was comparable between the three groups. Although there was no significant difference in the onset of sensory block and height of maximum sensory blockage between the three groups as shown in table 3 .

Table 1 Comparison of mean values of age and weight in the 3 groups

\begin{tabular}{|c|c|c|c|c|c|c|c|}
\hline $\begin{array}{l}\text { Gro } \\
\text { up }\end{array}$ & Age & $\begin{array}{l}\text { Mean } \pm \\
\text { SD }\end{array}$ & $p$ & Wt. & $\begin{array}{l}\text { Mean } \pm \\
\text { SD }\end{array}$ & $p$ & $\begin{array}{l}\text { Com } \\
\text { paris } \\
\text { on }\end{array}$ \\
\hline $\begin{array}{l}\text { A } \\
\text { n30 }\end{array}$ & $\begin{array}{l}22 \\
- \\
36\end{array}$ & $\begin{array}{l}28.43 \pm \\
3.84\end{array}$ & 0.1385 & $\begin{array}{l}56 \\
- \\
68\end{array}$ & $\begin{array}{l}62.10 \pm \\
2.89\end{array}$ & $>0.05$ & $\begin{array}{ll}A & \text { Vs } \\
B & \end{array}$ \\
\hline $\begin{array}{l}\text { B } \\
\text { n30 }\end{array}$ & $\begin{array}{l}21 \\
- \\
36\end{array}$ & $\begin{array}{l}26.90 \pm \\
4.05\end{array}$ & 0.8113 & $\begin{array}{l}57 \\
- \\
67\end{array}$ & $\begin{array}{l}62.23 \pm \\
2.76\end{array}$ & $>0.05$ & $\begin{array}{ll}\text { B } & \text { vs } \\
C & \end{array}$ \\
\hline $\begin{array}{l}\mathrm{C} \\
\mathrm{n} 30\end{array}$ & $\begin{array}{l}22- \\
35\end{array}$ & $\begin{array}{l}27.13 \pm \\
3.32\end{array}$ & 0.1668 & $\begin{array}{l}57- \\
69\end{array}$ & $\begin{array}{l}62.37 \pm \\
2.91\end{array}$ & $>0.05$ & $\begin{array}{ll}A & \text { vs } \\
C & \end{array}$ \\
\hline
\end{tabular}


Fig. 1 Mean heart rate variations in the three groups.

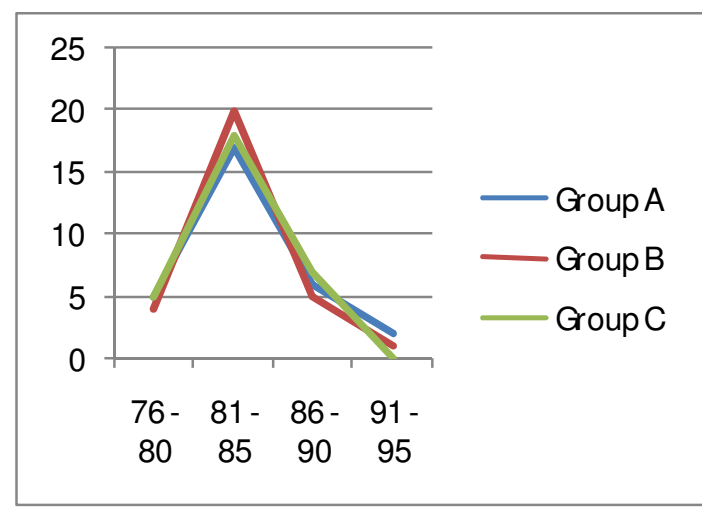

Table 2 Comparison of mean $\mathrm{SpO}_{2}$ of the three groups

\begin{tabular}{|c|c|c|c|c|c|c|c|c|}
\hline $\begin{array}{l}\mathrm{SpO} \\
2\end{array}$ & Group & $\begin{array}{l}\text { Ran } \\
\mathrm{e}\end{array}$ & & $\begin{array}{l}\mathrm{Me} \\
\text { an }\end{array}$ & SD & $\begin{array}{l}p \\
\text { value }\end{array}$ & $\begin{array}{l}\text { Signifi } \\
\text { cance }\end{array}$ & Comparison \\
\hline \multirow{3}{*}{$\begin{array}{l}\text { Bef } \\
\text { ore } \\
\text { Spin } \\
\text { al } \\
\text { Ana } \\
\text { esth } \\
\text { esia }\end{array}$} & A & $\begin{array}{l}92 \\
99\end{array}$ & - & $\begin{array}{l}95 . \\
43\end{array}$ & $\begin{array}{l}1.9 \\
8\end{array}$ & $\begin{array}{l}>0.0 \\
5\end{array}$ & NS & $A$ vs $B$ \\
\hline & B & $\begin{array}{l}92 \\
98\end{array}$ & - & $\begin{array}{l}95 . \\
03\end{array}$ & $\begin{array}{l}1.9 \\
6\end{array}$ & $\begin{array}{l}>0.0 \\
5\end{array}$ & NS & B vs $C$ \\
\hline & C & $\begin{array}{l}92 \\
99\end{array}$ & - & $\begin{array}{l}95 . \\
37\end{array}$ & $\begin{array}{l}2.0 \\
3\end{array}$ & $\begin{array}{l}>0.0 \\
5\end{array}$ & NS & $A$ vs $C$ \\
\hline \multirow{3}{*}{$\begin{array}{l}\text { Low } \\
\text { est } \\
\text { Rec } \\
\text { orde } \\
\text { d }\end{array}$} & A & $\begin{array}{l}93 \\
99\end{array}$ & - & $\begin{array}{l}97 . \\
37\end{array}$ & $\begin{array}{l}1.5 \\
4\end{array}$ & $\begin{array}{l}>0.0 \\
5\end{array}$ & NS & $A$ vs $B$ \\
\hline & B & $\begin{array}{l}94 \\
99\end{array}$ & - & $\begin{array}{l}96 . \\
70\end{array}$ & $\begin{array}{l}1.4 \\
9\end{array}$ & $\begin{array}{l}>0.0 \\
5\end{array}$ & NS & B vs C \\
\hline & C & $\begin{array}{l}94 \\
99\end{array}$ & - & $\begin{array}{l}97 . \\
03\end{array}$ & $\begin{array}{l}1.5 \\
9\end{array}$ & $\begin{array}{l}>0.0 \\
5\end{array}$ & NS & $A$ vs $C$ \\
\hline
\end{tabular}

Onset of sensory block had a mean \pm S.D. value of $4.417 \pm 0.439,4.403 \pm 0.432$ and $4.437 \pm$ 0.437 min respectively for groups A,B and C respectively but on comparing the time to 2 segment regression we obtained values of $115.23 \pm 2.73,127.60 \pm 6.03$ and $140.67 \pm 4.54$ respectively for groups $\mathrm{A}, \mathrm{B}$ and $\mathrm{C}$ which were statistically significant on comparison. Onset of motor block was comparable and statistically there was no significant difference between the three groups $(\mathrm{p}>0.05)$. However duration of motor block was $189.83 \pm 5.64,197.00 \pm 7.01$ and $220.30 \pm 9.70 \mathrm{~min}$ for groups A, B and C respectively, $\mathrm{p}<0.05$ on comparison.
Table 3 Spinal block Characteristics (mean +/- SD)

\begin{tabular}{|c|c|c|c|c|c|}
\hline & A & B & C & $p$ & $\begin{array}{l}\text { Signifi } \\
\text { cance }\end{array}$ \\
\hline $\begin{array}{l}\text { Time to } \\
\text { sensory } \\
\text { block to T4 } \\
\text { (min) }\end{array}$ & $\begin{array}{l}4.417 \quad \pm \\
0.43\end{array}$ & $\begin{array}{l}.403 \pm \\
0.432\end{array}$ & $\begin{array}{l}4.437 \pm \\
0.437\end{array}$ & $>0.05$ & NS \\
\hline $\begin{array}{l}\text { Time to } \\
\text { complete } \\
\text { motor block } \\
\text { (min) }\end{array}$ & $\begin{array}{l}4.75 \quad \pm \\
0.503\end{array}$ & $\begin{array}{l}4.770 \pm \\
0.199\end{array}$ & $\begin{array}{l}4.787 \pm \\
0.178\end{array}$ & $>0.05$ & NS \\
\hline $\begin{array}{l}\text { Time taken } \\
\text { for sensory } \\
\text { regression } \\
\text { to T12 (min) }\end{array}$ & $\begin{array}{l}115.23 \pm \\
2.73\end{array}$ & $\begin{array}{l}127.60 \pm \\
6.03\end{array}$ & $\begin{array}{l}140.67 \pm \\
4.54\end{array}$ & $<0.05$ & $S$ \\
\hline $\begin{array}{l}\text { Time to } \\
\text { complete } \\
\text { regression } \\
\text { of motor } \\
\text { block } \\
\text { (Bromage } 0 \text { ) }\end{array}$ & $\begin{array}{l}189.83 \pm \\
5.64\end{array}$ & $\begin{array}{ll}197 . & \pm \\
7.01 & \end{array}$ & $\begin{array}{l}220.3 \pm \\
9.70\end{array}$ & $<0.05$ & $S$ \\
\hline $\begin{array}{l}\text { Time from } \\
\text { injection to } \\
\text { 1st dose of } \\
\text { supplementa } \\
\text { I analgesia } \\
\text { (min) }\end{array}$ & $\begin{array}{l}263.30 \pm \\
7.57\end{array}$ & $\begin{array}{l}340.10 \pm \\
8.36\end{array}$ & $\begin{array}{l}700.00 \pm \\
8.65\end{array}$ & $<0.05$ & $S$ \\
\hline
\end{tabular}

Figure 2 Incidence of various side effects in different groups

Nausea was observed in 4 patients in group B and 5 patients in group C. Vomiting was noted in 7 patients in group B and 11 patients in group C.

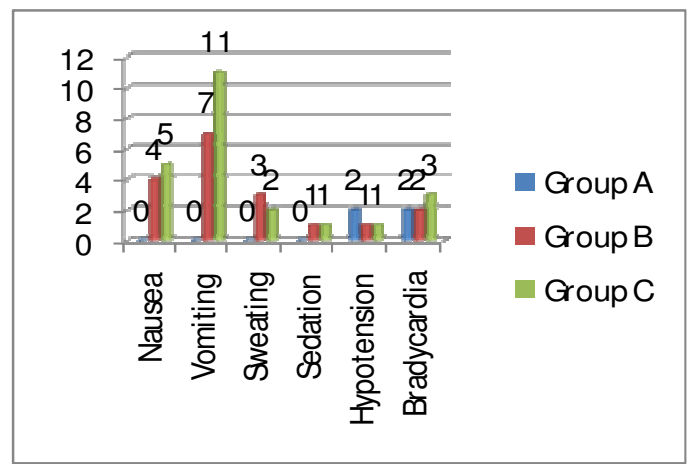


Table 4: VAS score at different postoperative time intervals in three groups

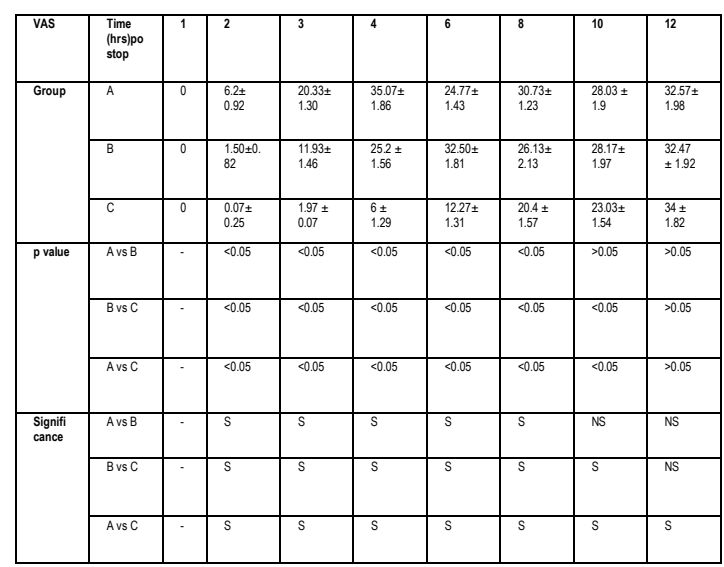

VAS at $1 \mathrm{hr}, 2 \mathrm{hr}, 3 \mathrm{hr}, 4 \mathrm{hr}, 6 \mathrm{hr}, 8 \mathrm{hr}, 10 \mathrm{hr}, 12 \mathrm{hr}$ \& $24 \mathrm{hr}$ in control group were higher and statistically significant $(\mathrm{p}<0.05)$ as compared to $50 \mu \mathrm{g}$ neostigmine $(\mathrm{p}<0.05)$ and $150 \mu \mathrm{g}$ neostigmine groups $(\mathrm{p}<0.05)$.

\section{Discussion}

The word "pain" is derived from Latin word "poena" meaning punishment. Pain is the most frequent and perhaps the oldest symptom. Pain is always subjective and is unique among all senses because it has a strong emotional component along with the sensory component. ${ }^{7}$ Recent research has revealed spinal cholinergic pathways and transmitters involved in antinociceptive processing. Intrathecal

Table 5: Comparison of Haemodynamic Parameters in three groups

\begin{tabular}{|c|c|c|c|}
\hline $\begin{array}{l}\text { Blood Pressure } \\
(\mathrm{mmHg})\end{array}$ & GROUP A & $\begin{array}{l}\text { GROUP } \\
\text { B }\end{array}$ & GROUP C \\
\hline \multicolumn{4}{|c|}{ Highest Systolic (Pre- operative) } \\
\hline Mean Systolic & $125.13 \pm 5.84$ & $\begin{array}{l}126.20 \pm 5.1 \\
6\end{array}$ & $125.80 \pm 4.88$ \\
\hline $\begin{array}{l}\text { Absolute(highest) } \\
\text { Systolic }\end{array}$ & 130 & 130 & 138 \\
\hline \multicolumn{4}{|c|}{ Highest Diastolic (Pre- operative) } \\
\hline Mean Diastolic & $79.20 \pm 5.60$ & $78.07 \pm 5.67$ & $77.73 \pm 5.96$ \\
\hline $\begin{array}{l}\text { Absolute(highest) } \\
\text { Diastolic }\end{array}$ & 79 & 78 & 92 \\
\hline \multicolumn{4}{|c|}{ Lowest Systolic (Intra operative) } \\
\hline Mean Systolic & $118.0 \pm 8.05$ & $\begin{array}{l}119.73 \pm 5.9 \\
4\end{array}$ & $119.73 \pm 5.30$ \\
\hline $\begin{array}{l}\text { Absolute(lowest) } \\
\text { Systolic }\end{array}$ & 104 & 106 & 108 \\
\hline \multicolumn{4}{|c|}{ Lowest Diastolic (Intra operative) } \\
\hline Mean Diastolic & $79.27 \pm 6.11$ & $78.47 \pm 6.34$ & $78.07 \pm 6.69$ \\
\hline $\begin{array}{l}\text { Absolute(lowest) } \\
\text { Diastolic }\end{array}$ & 60 & 64 & 62 \\
\hline
\end{tabular}

neostigmine, the cholinergic agent (a cholinesterase inhibitor) causes analgesia in humans. ${ }^{8}$ Acetylcholine being released from preganglionic sympathetic ganglia has been shown to have action at other spinal sites like inhibition of motor neuron activity and excitation of sympathetic outflow. ${ }^{2}$ Spinal neostigmine is advantageous over other currently used spinal drugs as it causes no hypotension (excitation of sympathetic outflow), no sedation, no respiratory depression or neurological dysfunction. ${ }^{2,3}$

In our study the mean lowest heart rate during spinal anaesthesia in all the three groups were comparable and statistically insignificant. On comparing the haemodynamic parameters, we found that the mean systolic blood pressure before spinal anaesthesia and the lowest mean systolic blood pressure and lowest mean diastolic blood pressure did not differ significantly between the three groups. None of the patients developed symptomatic bradycardia $(<50 \mathrm{bpm})$ or hypotension defined as a decrease in mean arterial blood pressure by $\geq 20 \%$. Lauretti et al ${ }^{9}$ showed similar observations but our study was in contrast to Hood et al ${ }^{8}$ who showed that spinally administered cholinergic agonist or cholinesterase inhibitors increase blood pressure and heart rate. The small dose (50-150 $\mu \mathrm{g}$ of neostigmine) could explain the lack of cardiovascular stimulation seen in our study. Hood et al used 500-750 $\mathrm{\mu g}$ of neostigmine in their study.

Mean oxygen saturation $\left(\mathrm{SpO}_{2}\right)$ and respiratory rate were comparable between the three groups and other similar studies ${ }^{8,10}$ with no patient developing hypoxemia $\left(\mathrm{SpO}_{2}<90 \%\right)$. There is no reported evidence of respiratory depression with the use of intrathecal neostigmine.

The highest sensory level achieved and time for onset of sensory block and onset of motor block (Bromage Grade II) were compared and were observed not to reach a statistically significant difference. The time for two segment regression of sensory block was prolonged in both the $50 \mu \mathrm{g}$ group $(127.6 \pm 6.03)$ and $150 \mu \mathrm{g}$ group $(140.67 \pm 4.54)$ as compared to the control group $(115.23 \pm 2.73)$ and showed a statistically significant difference of $<0.001$. Liu et $\mathrm{al}^{10}$ and Pan et $\mathrm{al}^{11}$ demonstrated similar prolonged durations of sensory block in their studies. 
Duration of motor block is significantly prolonged in the neostigmine $150 \mu \mathrm{g}$ group

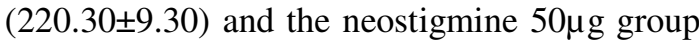
(197.0 \pm 7.01$)$ as compared to the Bupivacaine control group (189.83 \pm 5.64$)$, the comparison being statistically significant as was shown by similar dose neostigmine studies of Liu et $\mathrm{al}^{10}$ Tan et $\mathrm{al}^{12}$ and $\mathrm{Pan}$ et $\mathrm{al}^{11}$. Intrathecal neostigmine causes motor block by acetylcholine mediated reduction in motor neuron outflow with no reduction in spinal cord blood flow or histopathological changes ${ }^{8}$. In addition increased spinal levels may augment motor block of spinal bupivacaine ${ }^{10,12}$.

Analgesia provided by intrathecal neostigmine as assessed by visual analogue scale was also observed. VAS scores were compared at $1,2,3,4,6,8,10,12$ and 24 hour durations and showed a statistically significant $(\mathrm{p}<0.05)$ value when the 50 and $150 \mu \mathrm{g}$ neostigmine groups were compared with the control group. Our results are in agreement with Chung et $\mathrm{al}^{13}$ and Lauretti et $\mathrm{al}^{14}$ who demonstrated statistically significant lower visual analogue scale scores in the doses ranging from $25-75 \mu \mathrm{g}$ neostigmine group compared to saline group and studies done by Klam et $\mathrm{al}^{15}$ and Hood et $\mathrm{al}^{8}$.

The analgesic effects of cholinergic agonists and anticholinesterase agents have been demonstrated in several species including humans. Intrathecal administration of neostigmine produces analgesia in healthy volunteers by a spinal action in a dose dependent manner and the effective dose does not cause any neurological or cardio respiratory changes. ${ }^{8,16}$ Auto radiography have demonstrated muscarnic binding in the substantia gelatinosa and to a lesser extent in lamine III and V of gray matter of the spinal cord. $^{2}$ The effects of spinal neostigmine and edrophonium emphasize the relevance of the release of endogenous acetylcholine from spinal systems. ${ }^{17}$ This reflects that anti nociception is produced by inhibition of transmitter (ACh) metabolism. Although spinally administered agonist produce analgesia in all species tested, analgesia from cholinesterase inhibition depends on the degree of spinal cholinergic tone. $^{8}$

The total duration of analgesia was $263.30 \pm 7.57$ Hrs, $340.10 \pm 8.36 \mathrm{hrs}$ and $700 \pm 8.65 \mathrm{hrs}$ in control group, $50 \mu \mathrm{g}$ neostigmine and $150 \mu \mathrm{g}$ neostigmine respectively and showed statistically significant difference $(\mathrm{p}<0.05)$ when compared between the three groups.

All the patients were observed for any possible complications. Vomiting showed a statistically significant difference $(\mathrm{p}<0.05)$ between the control and study groups. Other similar studies done by Hood et $\mathrm{al}^{8}$, Lauretti et $\mathrm{al}^{9}$, Klamt $\mathrm{JG}^{15}$ etc. showed similar increase in the incidence of nausea and vomiting with similar dosages of neostigmine.

\section{Conclusion}

Intrathecal neostigmine results in effective analgesia postoperatively. Further it prolongs sensory and motor block induced by bupivacaine spinal anaesthesia and at the same time cause no haemodynamic or ventilator depression in the intraoperative and postoperative period. An increase in the incidence of nausea and vomiting was observed in both groups of neostigmine use.

\section{References}

1. IASP- International Association for the study of pain, pain terms: A list with definitions and notes on usage. Pain 1979; 6: 249-252.

2. Lauretti GR, Reis MP, Prado WA, Klamt.1G. Dose response study of intrathecal morphine versus intrathecal neostigmine, their combination or placebo for postoperative analgesia in patients undergoing anterior and posterior vaginoplasty. Anaesth Analg 1996 Jun; 82(6): 1182-7.

3. Hood DD, Mallak KA, Eisenach JC, Tong C. Interaction between intrathecal neostigmine and epidural clonidine in human volunteers. Anesthesiology 1996 Aug; 85(2):315-25

4. B.G. Covino. Pharmacology of local anaesthetic agents. Br. J Anaesth 1986; 58:701716.

5. Williams S, Tong C, Eisenach JC. Neostigmine counteracts spinal clonidine induced hypotension in sheep. Anaesthesiology 1993;78(2): 301-307.

6. Rose G, Xu Z, Tong C, Eisenach JC. Spinal neostigmine diminishes but does not abolish hypotension from spinal bupivacaine in sheep. Anesth Analg 1996; 83:1041-5.

7. Borsook D, Lebel AA and McPeek B. The Massachusetts' General hospital handbook of pain management.

8. Hood DD, Eisenach JC, Tuttle R. Phase I safety assessment of intrathecal neostigmine methylsulfate in humans. Anaesthesiolgy 1995; 82(2):331-43.

9. Lauretti GR, Reiss MP. Subarachnoid neostigmine does not affect blood pressure or 
heart rate during bupivacaine spinal anaesthesia.

10. Liu SS, Hodgson PS, Moore JM, Trautman WJ, Burkhead DL. Dose response effects of spinal neostigmine added to bupivacaine spinal anaesthesia in volunteers. Anaesthesiology 1999; 90 (3): 710 - 7.

11. Pan PM, Huang CT, Wei TT, Mok MS. Enhancement of analgesic effect of intrathecal neostigmine and clonidine on bupivacaine spinal anaesthesia. Reg Anaesth Pain Med 1998; 23(1):49-56.

12. Tan PH, Kuojh, Liu K, Hung CC. Efficacy of intrathecal neostigmine for the relief of post vaginal haemorrhaphy pain. Acta Anaesthesid. Sc 2000; 44; 1056 - 60.

13. Chung CJ, Kim JS, Park HS, Chin YJ. The efficacy of intrathecal neostigmine, intrathecal morphine, and their combination for postcaesarean section analgesia. Anesth Analg 1998 Aug; 87(2):341-6.
14. Lauretli CR, Hood DD, Eisench JC, Pfiefer BL. A multicenter study of intrathecal neostigmine for analgesia following vaginal hysterectomy. Anaesthesiology 1998; 89(4):913-8.

15. Klamt JG. Sluttitel A, Garcia IV, Prado WA. Postoperative analgesic effect of intrathecal neostigmine and its influence on spinal anaesthesia. Anaesthesia 1997; 52(6):547-51.

16. Eienach JC, Gebhart GE. Intrathecal amitriptyline. Antinociceptive interactions with intravenous morphine and intrathecal clonidine, neostigmine and carbamyl choline in rats. Anaesthesiolgy 1995; 83(5): 1036-45.

17. Naquib M, Yaksh TL. Antinociceptive effects of spinal cholinesterase inhibition and isobolographic analysis of the interaction with $\mu$ and $\alpha 2$-receptor systems. Anaesthesiology 1994; 80: 1338-1348.

\section{THE COLLEGE OF ANAESTHESIOLOGISTS OF SRI LANKA}

\section{Workshop \\ on \\ Primary Trauma Care}

$\begin{array}{ll}\text { Venue - } & \text { Trauma Lecture Hall } \\ \text { Date } & \text { National Hospital, Sri Lanka } \\ \text { Time } & \text { on Thursdays } \\ & 9.00 \text { am } \\ & \text { Contact } \\ & \text { Department of Anaesthesia, } \\ & \text { The National Hospital of Sri Lanka } \\ & 2 \text { 691111 ext. } 2571\end{array}$

